\title{
The Control of Information in Traditional Media through the Social Ones
}

\author{
Resul Sinani, Phd Cand. \\ Lecturer in Media and Communication Faculty at University for Business and Technology \\ resul.sinani@ubt-uni.net
}

Editor and Anchorman in RTK 1 (Public Television of Kosovo)

resulsinani@rtklive.com

\begin{abstract}
The usage of social media by Kosovar politicians is almost absolute. Politicians of all levels have their accounts on Facebook as well as other social networks. They use those for various reasons, starting from contacting the voters and supporters during the election campaigns as well as during the time they are in the office, up to presenting their stands and ideas that have do with different issues of public interest. For many of them, especially for low-level politicians the social media, mainly Facebook, have become the only place where they express themselves, since they find it almost impossible to become a part of the traditional media, especially of those on the national level, like newspapers, radio or television. Whereas for high-leveled politicians, concretely the heads of main institutions like the prime-minister, the head of parliament or the president, who refuse to be interviewed and be present in political shows where they could face questions from the journalists or the public, they are using Facebook statements in order to avoid direct questions from the journalists about the political subjects of the day. By making it impossible for them to take direct answers through their journalists the traditional media (newspapers, radio, TV) have to quote the posts that the politicians are making on Facebook. The kosovar journalists and the heads of media see this tendency of politicians, especially of the prime minister as the lack of transparency, avoidance of accountability, control of information and setting the agenda of the media. This paper attempts to argument the hypothesis that the high level politicians, the heads of main state institutions in Kosovo are controlling the information in traditional media through the usage of social media. In order to argument this hypothesis as a case study we have taken the Kosovar (ex)PM Hashim Thaçi whose almost every status and update has been quoted by the media. We have also interviewed journalists and editors of Kosovar media houses who have expressed their thoughts about the subject, while supporting the hypothesis of this paper.
\end{abstract}

Keywords: Social media, traditional media, information control, transparency, accountability, television.

\section{- INTRODUCTION}

The usage of Facebook in political communication is already finding widespread usage with Kosovar politicians. As well as, as a tool for promotion, where the politicians use it for their marketing, by publishing details about public activities and the presentation of their ideas and stands, Facebook is also used as a tool for controlling the information in the traditional media, which is done through their statuses which are then permanently quoted by the traditional media like the newspapers, radio and television stations. Quoting the status updates of high-level politicians in Kosovo has now become an absolute trend, a routine which cannot be opposed. Therefore the point of interest in this text is the stance that the journalists and the editors of some of the main media in the country have when it comes to this phenomenon. The politicians promote addressing the audiences through Facebook status updates as their transparency on front of the voters. Whereas the journalists see it as something completely opposite- as a complete lack of transparency since by doing nothing but publishing status updates without ever accepting to answer questions by the journalists the politicians are actually not transparent but are actually very selective in what they write. By not being able to get answers for the questions which interest them the media are limited to quoting statuses which are nothing more than exactly the messages, which the politicians want to send. Therefore, in this fashion they are managing to control the news (that comes from them) in the traditional media (radio, television and print). 
The Article is empiric and it researches the relationship between the media and the politicians in Kosovo, but its hypothesis can be valuable for every other country in which the relationship media-politicians are similar. Especially in the countries in which the media have accepted the condition and are do not have the power to pressure politicians into giving interviews but are satisfied with quoting their Facebook status updates. In order to argument the hypothesis of this article many journalists and editors of the Kosovar traditional media have expressed their stances through interviews. They have been answering questions that were concentrated around the four concepts through which the hypothesis of this article is being argumented. The text has been realized by concentrating on interviews, as an instrument of qualitative research, the vast majority of their answers did support the hypothesis and the concepts of the article. For this reason the answers of the participants have been presented and analyzed one by one, concept after concept.

\section{- $\quad$ LITERATURE REVIEW}

The role and influence of the media and journalism - as a ring in which the politicians face their voters has been noticed a long time ago. Toqueville notices that "the press, which knows so well how to ignite human passions is still not able to create them on its own". According to him the press fulfills these three major functions : 1) Guarantees freedom by exposing the secret mechanisms of politics (by forcing the politicians to stand in front of the court of public opinion) ; 2) Keeps the community together by giving the citizens joint references (only a newspaper can place the same idea in the minds of thousands of people in the same time); 3) Makes coordinated action possible in a quick manner (since it allows people and political parties to talk without seeing to each other ; meaning with no real contact) (Maigret, 2010. Pg45). These three functions of the press have, throughout media history, continued being applicable for all the other media. Each medium that has been invented and put to the service of informing the public has been seen as more democratizing for information and the society in general. Habermas (1974) sees the media as a place in which public space happens and develops, whilst with their theory of agenda setting McComb and Shaw (1972) argument the ability of the media to transfer the issues to the public. Today the social media have found a wide usage with the audiences- something made possible by the Internets ability to be interactive. Just as with all other previous types of media- with the appearance of on-line media a debate about the faith of other media- the traditional ones, as well as the roe and faith of journalists, has began. While talking about the faith of the journalistic profession and the impact of internet on it the journalist and the studier of Journalism and the media, Riccardo Stagliano (2004), through the hypothesis that "information becomes more democratic" and the anti-thesis "it is nothing but an un-believable market" hopes that finding a middle path and a synergy between the traditional and internet media. Whilst in a recent interview Bill Kovach, talks about the role and the responsibility of journalism. He does not believe that that it's role or responsibility have changed but, according to him they have become even more important. In this line of argumentation when talking about the dedication of journalism towards the truth in the time of internet and the plethora of media as well as the flux of information which circulates sees this exact phenomena as the main reason of making the role of journalism and journalists as the selector of the important information even more important and true:

"On the contrary, has become even more important. The truth is the most difficult to prove. Usually, we only approach the truth. With new technologies, we have thousands of lines of communication which is accessible to everyone, enough to have a computer. Today, people have to look at this huge amount of information to find out which things are verified, which are frauds, which are propaganda, and that fantasy. So this is the role of journalists now: help to clarify what is the truth in all that information."1

\section{- $\quad$ THE CONTROL OF INFORMATION IN TRADITIONAL MEDIA THROUGH THE SOCIAL ONES}

Among the traditional media in Kosovo television keeps leading as the medium through which most citizens get their information. Whereas when it comes to the credibility of the media traditional are still leading, in comparison with the online media, web-portals are particularly identified with the journalistic style of "yellow" press. Instead of being seen as democratizing and pluralizing the media scene the internet media are being identified as sensationalistic and show-biz oriented. Because of these circumstances the traditional media are the main point of interest for the politicians who want

\footnotetext{
1 http://www.zeriamerikes.com/content/bill-kovac-gazetari-legjendar-me-origjine-shqiptare-rrefen-jeten-135436328/519761.html
} 
to present their activities and express their ideas. When it comes to the communication of the politicians of various levels - for the low-level politicians such as municipal level politicians social networks are an excellent platform for communicating with the voters. This is because they seldom have a chance to get a spot in the traditional media. But this article is focused on high-level politicians and their relationship with the media. Through interviews with the journalists and the editors of the most important media in the country this article attempts to answer four main questions: 1) how do they see the trend of quoting Facebook statuses (social media) of high-level politicians?; 2) DO they think that quoting these statuses represents an increase or as lack of transparency?; 3) ... The mission of the media is to place the politicians in front of the public... are the politicians avoiding accountability by quoting Facebook status updates?; 4) Are Facebook's status updates being used as a tool for controlling the news?

Most of the interviewees look at the first question : the trend of quoting Facebook statuses (social media) of high-level politicians with a large dose of skepticism. In a few instances they see it as something positive but it is generally seen as a negative occurrence because through this practice the role of the media and the journalists has been eliminated. While a politician will write only what interests him, not what is of interest for the journalist and the public in his status updates. For Agron Bajrami the editor in chief of the daily newspaper Koha Ditore, quoting FB statuses symbolizes passive and uneffective journalism which does not ask questions or follow the news but allows politics to dictate the subjects and the way of reporting. Furthermore he adds:

"The practice of posting statements through Facebook has become widespread with the politicians since it allows them to speak about the subjects, which they want to speak about and avoid answering questions and issues which can be problematic or controversial but speak only of the things which they see as promotional for their goal and themselves. The role of the media is not to promote politics and policies but to ask critical questions about the problems and issues which are of interest for the citizens and the country. Therefore the practice of filling the news with the statements taken from facebook and other social networks or even from official press releases is not in the interest of full and correct informing the public and it does not help the credibility of the media it is the exact opposite. Such passive journalism which simply reports what the politician wishes to say and does not ask questions becomes a simple propaganda tool which, at the end of the day cannot even be called journalism."1

Yet, Agron Bajrami, does not completely eliminate the possibility of quoting the Facebook status of politicians since, according to him, there are cases when politicians do give statements of interest which should be quoted. According to him quoting Facebook status updates should not be completely eliminated, but it should not become the main pillar of journalistic reporting. Jeta Xharra ${ }^{2}$, the editor in chief of the Balkan Investigative Reporting Network BIRN also thinks that investigative journalists can be helped by politician's statuses, since- with it being an "in-formal" and "relaxing" media the politicians do reveal their true nature through them. She confesses that by getting information from politician's statuses BIRN reporters started investigating some rather important cases ${ }^{3}$. But, these are not cases when they simply quoted the status update, but it was used as a starting point of in-depth journalistic investigation. Llukman Halili, an experienced journalist and an editor of a newspaper in Switzerland calls the practice of quoting updates "Copy paste which has nothing to do with the situation to which the status is referring to" ${ }^{4}$. While Gjergj Filipaj, an editor of RTK1 news sees the social networks as something new and a new opportunity for communication between the government officials and citizens. But when it comes to directly quoting the updates he does not think that it should become the only way of communicating. Furthermore, he says:

"I think the communicating through social networks- through Facebook statuses should be a part of communication but it should not completely replace traditional communication of the government with the media and the people. So using status updates as quotes can be done, but only after all other means of communication have been tried: press releases, TV

\footnotetext{
${ }^{1}$ Agron Bajrami, Editor in chief of Koha Ditore. Interview for the author done for this article.

2 Jeta Xharra, Co-Founder at Gazeta Jeta në Kosovë, Anchor and editor in Chief at emisioni Jeta në Kosovë, executive Director at BIRN.

3 The case of giving the tender for Kosova E Re termocentral without having three bidders was firs found out from the PM-s facebook and then the information was published by the "Leading comitee". This was noticed by the civil society through a reaction which can be found at http://kosid.org/news/47. The case when the story that the former American Ambassador in Kosovo Chris Dell was working in africa for Bechtel, the company for which he lobbied while he was in Kosovo, BIRN started out from a post on FB. shih http://www.theguardian.com/world/2014/apr/14/us-ambassador-kosovo-construction-contract-firm-highway.

${ }^{4}$ Llukman Halili. Editor at www.dialogplus.ch
} 
interviews, joint reporting, news agency interviews. Writing statuses should not become the only way of communication with the media and the population."1

While, Lorik Arifaj the editor in chief of Kosovar Public television sees the development of technology and quoting statuses as quite a positive step. He thinks that "using the personal pages of the social networks by the politicians, are helpful when it comes to the speed of the news. Maybe they are less damaging to TV stations since it is well known that on TV the most important element is the picture, or video, while it is extremely helpful for web-portals." According to Arben Ahmetin, the editor in chief of the daily Tribuna, dislikes quoting statuses. According to him even "quoting opinions, not only stands, but opinions of, for example, ex-PM Thaci, shows lack of respect and sucking up to the government". Zekiria Shabani, an editor of the economic section in the daily Tribuna, and the head of the Association of Kosovar Journalists sees the trend of quoting status updates as harmful for journalism and information in general. He adds:

"This has become the only for open communication between the politicians and public in Kosovo and it has unfortunately been accepted as such by the media. Quoting status updates is nothing wrong, for as long as you apply the standards of correct reporting within journalism. But, in most cases, the media suffice with a status update posted by some politician without even checking of its truthfulness first and then following the story till the end in order to present the public with the truth. The media must understand that facebook is a gate for communication between a politician and the public with the role of the media is to go beyond being an in-between during communication."3

While when it comes to the second question, one if quoting status updates represents an increase in transparency or lack of transparency most of the interviewees believe it represents lack of transparency. This phenomenon they see as: an absolute lack of transparency (Halili), as insufficient, since lack of transparency is a total lack of information (Filipaj), transparency is not posting or publishing what is of interest for the politician but what is of public interest (Shabani), or as two-sided, transparent since it allows to directly take the stances of the persons who are competent, not through press representatives, but it is also lack of transparency, since each politician is guarded in what he expresses since no one can interfere with the wording which transmits only what the author wanted to say and nothing more (Arifaj). And Agron Bajrami, while elaborating on the subject says:

"This has nothing to do with transparency, This is propagandaa whose purpose is more to manipulate the public than answer relevant questions. We, until now, have not seen a single post made by a politician which speaks of the failures of their policies, which speaks of the deficiencies of their governance, of unfulfilled promises, of being unable to improve the quality of life! We have constantly seen promotions of their so called successes or, in some rare cases, attempts to explain a failure, by trying to throw the blame somewhere else"4

By denying transparency through such a form, Jeta Xharra, as an argument, uses a research done by BIRN which had to do with access to official documents. During one year there were about 300 requests for access to public institutions but only $30 \%$ of them have been answered Jeta Xharra ${ }^{5},{ }^{6}$. She adds:

"In case of the PM Thaçi, it is known that he did not have a spokesperson but he did have Facebook status updates. This tells of how serious he is that he is ready to place people "in the background" who will post things for him but none of them will openly admit that he is speaking instead of the PM. This, in a way, shows that he was not able to find a person that he trusts and who will put his credibility on the line and allow himself be the face of the government. This in itself tells a lot."

About the third question in this research, are trough FB statuses and by quoting them in the media, if are the politicians avoiding accountability by quoting Facebook status updates? The interviewees almost completely agree, that accountability is being avoided massively, or at last there are endless attempts to avoid it. The opinions of the interviewees

\footnotetext{
1 Gjergj Filipaj, News editor at RTK 1.

2 Lorik Arifaj, Temporary Editor in Chief at RTK 1.

3 Zekiria Shabani, The head of the association of Kosovar Jounalists AGK. Interview for the author done for this article.

${ }^{4}$ Agron Bajrami, Editor in chief of Koha Ditore. Interview for the author done for this article.

${ }^{5}$ Jeta Xharra, Co-Founder at Gazeta Jeta në Kosovë, Anchor and editor in Chief at emisioni Jeta në Kosovë, executive Director at BIRN.

${ }^{6}$ For more, see the BIRN report.

http://jetanekosove.com/repository/docs/Raporti_per_qasje_ne_dokumente_publike_final_final_87217.pdf

7 Jeta Xharra, Jeta Xharra, Co-Founder at Gazeta Jeta në Kosovë, Anchor and editor in Chief at emisioni Jeta në Kosovë, executive Director at BIRN.
} 
range from politicians using FB for cosmetic needs and re branding therefore it is proof of a failed attempt to avoid accountability (Halili), as complete avoidance of accountability by the leaders (Shabani), not only that accountability is being avoided, but it is non-existent since the media itself is content with quoting status updates thus allowing politicians to function in this way (Bajrami). Whereas Lorik Arifaj says "I do not think that they are avoiding accountability. This can be done in various TV debates. Interviews or press conferences when they talk of other issues and which can be used by the journalists who want to complete a certain subject"But live interviews and debates in which the politicians appear, especially the high-level ones, like for example the PM, or the ex-PM Thaçi, according to Jeta Xharra are pre-selected. According to her former PM Thaçi has never accepted being a guest of her show 'Jeta në Kosovë' during the entire time he was in the government, but only while he was with the opposition it is clear that he has been choosing the media and the journalists in which he was certain he will not face critical questions. Therefore, for Jeta Xharra, no matter how much the politicians try to avoid accountability the public is still aware of what they are doing.

And when we speak of the fourth question, are the politicians using their fb statuses as means for controlling the news, all the interviewees agree that there is such a tendency with the politicians, but say that it is not the same for all media. They believe that media and journalists will manage to resist this tendency but, for the time being there is a trend of quoting updates by the traditional media and this makes the politicians use only this form of communication and refusing to accept direct confrontation with the media and the journalists, or even when they do agree to something like that, they choose "friendly" shows and journalists who will not be critical towards them. The reasons why the media is involved in all of this range from are from economical up to subduing some media by politics. These tendencies are believed to be doomed a failure (Halili), as a result of the lack of finances the media have available in order to have more reporters who move quickly after the news has been published (Shabani), but that journalists who are skillful and have integrity should not stop in front of challenges and problems thus not allow themselves to be influenced by status updates of any politician (Filipaj). If there is no control of the news than there can be no orientation according to the agendas of the politicians, but it is the editorial staff who decides the importance or the direction that they should give to a story (Arifaj). While in the Kosovar media reality, the FB updates of politician's statuses are becoming the news agenda for the editors and lazy journalists who allow themselves to create the news solely through updates without following up on other reactions and checking them in reality (Xharra). While at the end, the editor in chief of Koha Ditore, Agron Bajrami, after concluding that the politicians are managing, up to a point, to control the news that comes from them and encompasses the story about their political activities, says:

"As I said before, the posts of the politicians on social networks are propaganda whose purpose is to sink the story and instead of truth offer political manipulation. Of course, politicians do not always manage to control the news since not all Kosovar media depend of social network updates. Furthermore one of the more positive aspects is that the more credible media in Kosovo, like Koha Ditore, are not dependent of politicians Facebook updates and official press releases. The vast majority of the news today there are result of active, investigative, critical journalism whose purpose is to follow the truth as deep as possible."1

\section{- $\quad$ CONCLUSION}

Kosovar politicians, especially the high-level ones, which best illustrated by the example of the ex-PM Thaçi, are widely using Facebook for promoting their activities. Their statuses are being actively quoted by the traditional media, like the newspapers, radio and television. This is seen as sufficient and more useful by the politicians while it is also seeen as lack of transparency and even a tendency for controlling the news by journalists and the editors of kosovar media. Through answering the four questions in the article, journalists and editors of the Kosovar media argument the hypothesis of this article that through the usage of the social media politicians of the highest level, the leaders of the main government institutions are controlling the information in the traditional media.

\section{REFERENCES}

Agron Bajrami, Editor in chief of Koha Ditore. Interview for the author done for this article 
[1] Habermas, Jürgen. "The Public Sphere" 1974, printed in The Information Society Reader, (New York: Routledge, 2004), p. 350-353.

[2] Kovach, Bill, (2015). Intervistë nga gazetari i Zërit të Amerikës, llir lkonomi. http://www.zeriamerikes.com/content/billkovac-gazetari-legjendar-me-origine-shqiptare-rrefen-jeten-135436328/519761.html.

[3] McCombs, M; Shaw, D (1972). "The agenda-setting function of mass media". Public Opinion Quarterly. Taken from: http://www4.ncsu.edu/ amgutsch/Mccombs.pdf.

[4] Maigret, Eric. (2010). Sociologjia e Kominikimit dhe e Mediave. UET Press \& Papirus. Tiranë. 2010.

[5] Stagliano, Riccardo (2004). "Gazetaria 2.0. Të merresh me informacion në kohën e internetit". ISHM, Tiranë.

[6] Agron Bajrami, Editor in chief of Koha Ditore. Interview for the author done for this article. He has been working in journalism since the 1990-s, at fiorst as a jounalisst in Koha Magazine while since 1997 for the Koha Ditore daily.

[7] Arben Ahmeti, Head editor at the daily Tribuna. Inteview for the author of this article. Long time jounalist, he has worked for Koha Ditora, while since Tribuna started out he has been its head editor. Now works as the presenter of the morning edition at Radio Dukagjini.

[8] Gjergj Filipaj, News Editor at kosovar Public Television RTK 1. Interview for the author of the article given for the purposes of this writing. Master of journalism and communication, a long-time reporter who was worked for Koha Ditore and Zëri.

[9] Jeta Xharra, Editor of the Jeta në Kosovë Show and the executive director of Balkan Network of Investigative Jounalism BIRN. linteview for the author of this article. Known as the author and moderator of the Jeta në Kosovë show and she is the co-founder of the newspaper Jeta në Kosovë.

[10] Llukman Halili, Editor at www.dialogplus.ch. Intervew for the author of this article. Phd of political sciences, journalist and editor at Prishtina Television during 1980-s. Long time editor at Bota Sot. Currently a co-founder and editor of the on-line magazine Dialog Plus.

[11] Lorik Arifaj, Editor in chief of kosovar public television RTK1. Inteview given to the author of the article. During his career he has also been a program producer and a news-editor at RTK1.

[12] Zekiria Shabani, The head of the Association of Kosovar journalists AGK and an economy editor at the Tribuna daily. Interview for the author of this article.

[13] BIRN June 2013. Shteti 30\% i qasshëm për Qytetarët. http://jetanekosove.com/repository/docs/Raporti_per_qasje_ne_dokumente_publike_final_final_87217.pdf. 